\title{
Affordances for Capturing and Re-enacting Expert Performance with Wearables
}

\author{
Will Guest ${ }^{1}$, Fridolin Wild ${ }^{1}$, Alla Vovk ${ }^{1}$, Mikhail Fominykh ${ }^{2}$, Bibeg Limbu ${ }^{3}$, Roland \\ Klemke $^{3}$, Puneet Sharma ${ }^{4}$, Jaakko Karjalainen ${ }^{5}$, Carl Smith ${ }^{6}$, Jazz Rasool ${ }^{6}$, \\ Soyeb Aswat ${ }^{7}$, Kaj Helin ${ }^{5}$, Daniele Di Mitri ${ }^{3}$, and Jan Schneider ${ }^{3}$ \\ ${ }^{1}$ Oxford Brookes University, UK \\ ${ }^{2}$ Europlan UK ltd., UK \\ ${ }^{3}$ Open University of the Netherlands, \\ Netherlands \\ ${ }^{4}$ University of Troms $\varnothing$, Norway \\ ${ }^{5}$ VVT, Finland \\ ${ }^{6}$ Ravensbourne, UK \\ ${ }^{7}$ Myndplay, UK

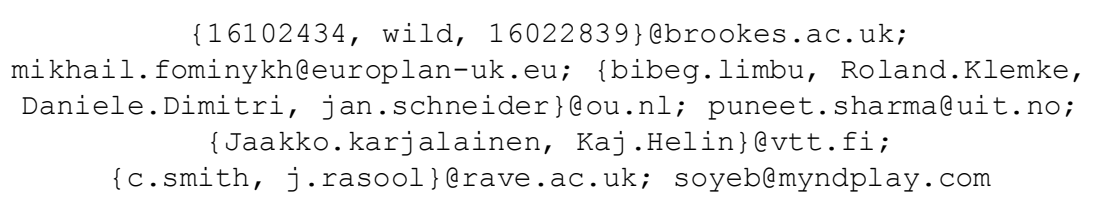

\begin{abstract}
The WEKIT.one prototype is a platform for immersive procedural training with wearable sensors and Augmented Reality. Focusing on capture and re-enactment of human expertise, this work looks at the unique affordances of suitable hard- and software technologies. The practical challenges of interpreting expertise, using suitable sensors for its capture and specifying the means to describe and display to the novice are of central significance here. We link affordances with hardware devices, discussing their alternatives, including Microsoft Hololens, Thalmic Labs MYO, Alex Posture sensor, MyndPlay EEG headband, and a heart rate sensor. Following the selection of sensors, we describe integration and communication requirements for the prototype. We close with thoughts on the wider possibilities for implementation and next steps.
\end{abstract}

Keywords: Affordances, Augmented reality, Wearable technologies, Capturing expertise.

\section{Introduction}

In recent years, delivery devices and sensor technology evolved significantly, while costs of hard- and software and development kits decreased rapidly, bringing about novel opportunities for the development of multi-sensor, augmented reality systems that will be investigated here for their ability to contribute to the much needed continuous up-skilling of already skilled workers (to support product innovation), as they usually do not get enough vocational training in Europe: According to the Eurostatôs lifelong learning statistics, e.g., the EU-27 show only a participation rate of $10.7 \%$, instead of the 2020 target of $15 \%$ [1].

In this paper, we elaborate which affordances are both possible and needed for 
capturing of expert experience and its guided re-enactment by trainees. Our understanding of áffordanceô beginning with Gibsonôs notion of a subject finding usefulness in their environment [2], finds interesting application with the inclusion of virtual elements into the environment, specifically those with which the user can interact. Affordances are opportunities for action and belong neither to the environment nor to the individual directly, but rather to the relationships between them [3].

Capturing and re-enactment of expert performance is a form of Performance Augmentation, serving, for example, as scaffold in training procedural tasks, possibly increasing training efficiency (reduced time to competence, increased number of iterations at same cost, with less constraints on trainer involvement) and training effectiveness (error proofing with more active learning under direct guidance).

In this paper, we unravel affordances that are conducive to capturing and reenactment of experience. We outline recent work in this domain (Sec. 2), those affordances of particular interest and the hardware selection that offers them (Sec. 3), and, finally, concluding remarks with next steps and current limitations (Sec. 4).

\section{Background and Related Work}

Ericsson and Smith define expert performance as consistently-superior, effective behaviour on a specified set of representative tasks [4]. Expert performance can be attained in a particular domain through collecting experience in a deliberate manner, differing from everyday skills in the level of proficiency as well as in the level of conscious and continuous planning invested into updating and upgrading.

Apprentices often collect experience in their craft through hands-on practice under supervision of an expert, rather than from written manuals or textbooks. As Newell and Simon propose, the outstanding performance of the expert is the result of incremental increase in knowledge and skill due to continuous exposure to experience [5]. Enabling experts to share their experience with apprentices in a perceptible way is an essential aspect of expertise development.

Wearable sensors and AR bear potential to capture expert performance and knowledge contained in a training activity. If knowledge is stored in such learning activity, it can be re-experienced many times over, analysed, and reflected upon, individually or collaboratively [6,7]. AR then provides a rich multimodal and multisensory medium for apprentices to observe captured expert performance. Such medium enriches the apprenticeôs experience, augmenting their perception through visual, audio, and haptic modes. AR overlays virtual content on the real environment to create an immersive platform [8,9], placing the apprentice in a real-world context, engaging all senses. Augmented perception allows better interaction with the environment [10], equipping apprentices with better tools to mimic expert performance and build knowledge. Fominykh et al. provide an overview on existing approaches for capturing performance in the real world [6], with consideration also given to the tacit knowledge and the its role in learning new tasks. 
Table 1. Affordances in capturing and re-enactment of expert performance using sensors

\begin{tabular}{llll}
\hline Affordance & $\begin{array}{l}\text { Applications for } \\
\text { Prototype }\end{array}$ & Sensor types & $\begin{array}{l}\text { Related } \\
\text { work }\end{array}$ \\
\hline $\begin{array}{l}\text { Virtual/tangible manipulation, } \\
\text { object enrichment }\end{array}$ & $\begin{array}{l}\text { Record of inertial } \\
\text { data }\end{array}$ & $\begin{array}{l}\text { Wireless inertial } \\
\text { sensor, depth camera }\end{array}$ & {$[10-15]$} \\
\hline $\begin{array}{l}\text { Contextualisation, In situ real } \\
\text { time feedback, haptic hints }\end{array}$ & $\begin{array}{l}\text { Record of Force } \\
\text { applied }\end{array}$ & Pressure sensor & {$[16,17]$} \\
\hline $\begin{array}{l}\text { Directed focus, } \\
\text { Contextualisation }\end{array}$ & $\begin{array}{l}\text { Record of eye } \\
\text { tracking data or } \\
\text { gaze direction }\end{array}$ & $\begin{array}{l}\text { Eye tracker, } \\
\text { gyroscope }\end{array}$ & {$[18,19]$} \\
\hline Self-awareness of physical state & $\begin{array}{l}\text { Monitor and record } \\
\text { physiological data }\end{array}$ & $\begin{array}{l}\text { EEG, EMG, ECG, } \\
\text { gyroscope, } \\
\text { accelerometer, VHR }\end{array}$ & {$[17,20-22]$} \\
\hline $\begin{array}{l}\text { Virtual post it (annotation), } \\
\text { Contextualisation }\end{array}$ & $\begin{array}{l}\text { Record annotations } \\
\text { and display in AR }\end{array}$ & $\begin{array}{l}\text { AR and spatial } \\
\text { environment }\end{array}$ & {$[12,23]$} \\
\hline Think aloud & Record audio & Microphone & {$[24]$} \\
\hline $\begin{array}{l}\text { Remote symmetrical tele- } \\
\text { assistance, zoom }\end{array}$ & Record video & Camera & {$[24]$} \\
\hline
\end{tabular}

\section{$3 \quad$ Affordances for Capturing and Re-Enactment}

The WEKIT framework guides the sensor selection process [7] identifying affordances that allow the capture of specific key aspects of expert performance and provision of affordances to the trainees in re-enactment (Table 1). For each affordance, suitable technological solutions are considered together with the type of sensor that would need to be used.

The proposed hardware framework for capturing expertise and re-enactment is depicted in Figure 1, accommodating for comfort, wearability and accessibility.

This hardware platform uses panels incorporated into the garment to encase both the Myo Armband and the heart rate sensor at the wrist, with wire casing running up the outer sleeve. Sensors sit flat against the body and do not move about with wear. The hardware prototype integrates sensors in total a wearable item of clothing, connecting a Microsoft Hololens, a Thalmic Labs MYO, an Alex Posture sensor, an EEG headband, and a heart rate sensor [25]. The garment provides an inclusion for wires of posture

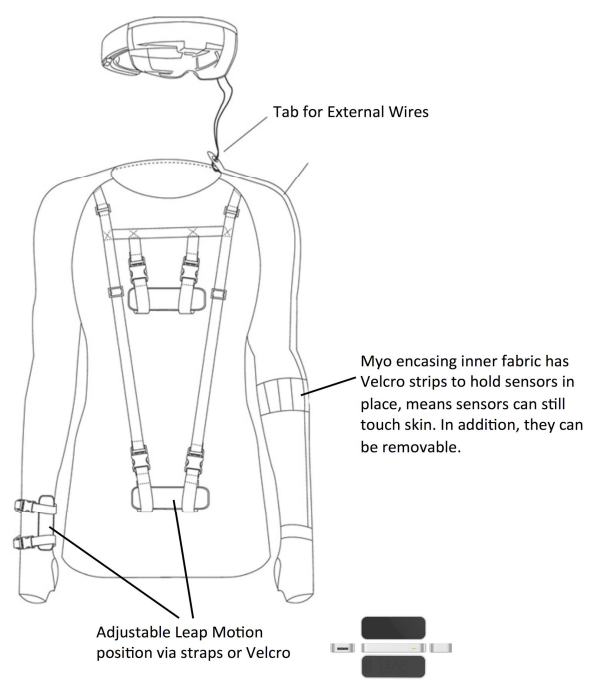

Figure 1. WEKIT wearable solution 
sensor and armband connecting them with the smart glasses. Additional, adjustable casings for Leap Motion sensors were designed for use on the arms and torso.

Choosing AR glasses was based on a requirements analysis report [25]. After taking into consideration features such as built-in microphone array, environment capture, gesture tracking, mixed reality capture, Wi-Fi 802.11ac, and fully untethered holographic computing, Microsoft Hololens was selected. Furthermore, the built in components of Hololens enable us to capture several different attributes of the user and her environment. For EEG, the MyndBand and Neurosky chipset were favoured due to the availability of the processed data and real time feedback. For detecting hand, arm movements and gestures: Leap Motion and Myo armband were chosen. To track the position and angle of the neck, Alex posture tracker was suggested.

Table 2. Selected Sensors and Requirements for Capturing, and Re-enactment

\begin{tabular}{|c|c|c|c|}
\hline Sensors & $\begin{array}{l}\text { Requirements for } \\
\text { capturing affordances }\end{array}$ & $\begin{array}{l}\text { Requirements for re- } \\
\text { enactment affordances }\end{array}$ & $\begin{array}{l}\text { Requirements } \\
\text { for bandwidth }\end{array}$ \\
\hline $\begin{array}{l}\text { AR Glasses } \\
\text { (Hololens) }\end{array}$ & $\begin{array}{l}\text { Track location of user } \\
\text { and objects in the } \\
\text { environment. }\end{array}$ & $\begin{array}{l}\text { View instructions, } \\
\text { activity, videos, and } \\
\text { virtual post-its, } \\
\text { application. }\end{array}$ & $\begin{array}{l}\text { High }(60 \mathrm{fps}, \\
\text { maximum } \\
\text { resolution } 1268 \\
\text { by } 720 \text { per eye })\end{array}$ \\
\hline $\begin{array}{l}\text { Point of view } \\
\text { camera } \\
\text { (Hololens) }\end{array}$ & $\begin{array}{l}\text { Start/stop video } \\
\text { recording, take digital } \\
\text { pictures, enable/ disable } \\
\text { camera, capturing } \\
\text { current view. }\end{array}$ & $\begin{array}{l}\text { Capturing current point } \\
\text { of view, enable/ disable } \\
\text { point of view camera. }\end{array}$ & $\begin{array}{l}\text { High }(2.4- \\
\text { megapixel } \\
\text { resolution) }\end{array}$ \\
\hline $\begin{array}{l}\text { Built-in } \\
\text { microphone } \\
\text { (Hololens) }\end{array}$ & $\begin{array}{l}\text { Start/stop the } \\
\text { microphone, } \\
\text { enable/disable } \\
\text { microphone. }\end{array}$ & $\begin{array}{l}\text { Start/ stop the } \\
\text { microphone, enable/ } \\
\text { disable microphone. }\end{array}$ & $\begin{array}{l}\text { Moderate (4 } \\
\text { audio streams) }\end{array}$ \\
\hline $\begin{array}{l}\text { Gaze } \\
\text { (Hololens) }\end{array}$ & $\begin{array}{l}\text { Estimate gaze direction, } \\
\text { select objects in the } \\
\text { environment, place } \\
\text { virtual post-its. }\end{array}$ & $\begin{array}{l}\text { Estimate gaze direction, } \\
\text { select objects in the } \\
\text { environment, place } \\
\text { virtual post-its. }\end{array}$ & $\begin{array}{l}\text { Low (XYZ } \\
\text { coordinates) }\end{array}$ \\
\hline $\begin{array}{l}\text { MyndBand } \\
\text { and Neurosky } \\
\text { chipset }\end{array}$ & $\begin{array}{l}\text { Estimate attention, } \\
\text { focus eye blinks, and } \\
\text { other metrics, } \\
\text { enable/disable EEG. }\end{array}$ & $\begin{array}{l}\text { Estimate attention, } \\
\text { focus eye blinks, and } \\
\text { other metrics, enable/ } \\
\text { disable EEG. }\end{array}$ & $\begin{array}{l}\text { Low (Attention } \\
\text { and stress } \\
\text { levels, range } \\
[0,100])\end{array}$ \\
\hline Leap Motion & $\begin{array}{l}\text { Recognize hand } \\
\text { movements and } \\
\text { gestures. }\end{array}$ & $\begin{array}{l}\text { Recognize hand } \\
\text { movements and } \\
\text { gestures. }\end{array}$ & $\begin{array}{l}\text { Moderate (3D } \\
\text { model, skeleton } \\
\text { data) }\end{array}$ \\
\hline $\begin{array}{l}\text { Position } \\
\text { tracker (Myo) }\end{array}$ & $\begin{array}{l}\text { Recognize gestures and } \\
\text { location of user }\end{array}$ & $\begin{array}{l}\text { Recognize gestures, use } \\
\text { vibrations as feedback } \\
\text { on some activities. }\end{array}$ & $\begin{array}{l}\text { Low (XYZ } \\
\text { coordinates and } \\
\text { gestures) }\end{array}$ \\
\hline $\begin{array}{l}\text { Electromyogr } \\
\text { am (Myo) }\end{array}$ & $\begin{array}{l}\text { Recognise hand } \\
\text { movements }\end{array}$ & $\begin{array}{l}\text { Recognise hand } \\
\text { movements }\end{array}$ & Low (gestures) \\
\hline $\begin{array}{l}\text { Alex posture } \\
\text { tracker }\end{array}$ & Recognize posture. & Vibration feedback. & $\begin{array}{l}\text { Low (XYZ } \\
\text { coordinates) }\end{array}$ \\
\hline
\end{tabular}

In Table 2, we look at the requirements associated with capturing, re-enactment, and 
data bandwidth. We can clearly see that different sensors require different bandwidths. It is particularly high for video signals (e.g., AR display, Point of view) and low for Myo, Myndband, and Alex posture tracker.

\section{$4 \quad$ Concluding Remarks}

Understanding that both expert and learner advance from the affordances provided by wearable technology, we make begin to weave together the requirements for maximising the benefit at each stage of knowledge transfer. This paper summarises the integration of new knowledge on the pedagogical level (by creating the WEKIT learning framework), technological level (by designing a hard- and software for capturing and re-enactment of expertise), and on the semantic level (by describing a process model for sharing and dissemination of task performance).

As a training method, expertise capturing needs to complement existing/new technical documentation. It has to be done at the right level of abstraction and enabling comparison of performances using the recorded data. Both knowledge capture and representation should strive to blend with the user's actions, considering the manner in which information is conveyed and ensuring that it is realistic, believable and correct. With the right hardware and a software platform, this method will provide trainees with a useful approximation to the full experience of becoming the expert, enabling immersive, in-situ, and intuitive learning just as a traditional apprentice would, following in the footsteps of the master and fitted with the specialist knowledge of technical communicators.

\section{References}

1. Eurostat: Lifelong learning statistics. (2016), http://ec.europa.eu/eurostat/statisticsexplained/index.php/Lifelong_learning_statistics

2. Gibson, James J. "The theory of affordances. Shaw \& Bransford (Eds.): Perceiving, acting, and knowing: Toward an ecological psychology (pp. 67ï 82)." (1977)

3. Rizzo A.: The origin and design of intentional affordances. In: Proc 6th Conf Designing Interactive systems, University Park, PA, USA, pp. 239ї 240. ACM, New York (2006)

4. Ericsson K.A., Smith J.: Prospects and limits of the empirical study of expertise: An introduction. In: Ericsson KA, Smith J (eds.) Toward a general theory of expertise: Prospects and limits. pp. 1-39. Cambridge University Press, Cambridge, UK (1991)

5. Newell A., Simon H.A.: Human problem solving. Prentice Hall, Englewood Cliffs, NJ (1972)

6. Fominykh M., Wild F., Smith C., Alvarez V., Morozov M.: An Overview of Capturing Live Experience with Virtual and Augmented Reality. In: Preuveneers (ed.) Workshop Proceedings of the 11th International Conference on Intelligent Environments, pp. $298 \mathrm{i} 305$. IOS Press, Amsterdam, Netherlands (2015)

7. Limbu B., Fominykh M., Klemke R., Specht M., Wild F.: Supporting Training of Expertise with Wearable Technologies: The WEKIT Reference Framework. In: The International Handbook of Mobile and Ubiquitous Learning. Springer, New York (2017) 
8. Bacca J., Baldiris S., Fabregat R., Graf S., Kinshuk: Augmented Reality Trends in Education: A Systematic Review of Research and Applications. Educational Technology \& Society 17 (4), 133 Ï 149 (2014)

9. Bower M., Sturman D.: What are the educational affordances of wearable technologies? Computers \& Education 88, 343 ï 353 (2015)

10. Wagner R.K., Sternberg R.J.: Practical intelligence in real-world pursuits: The role of tacit knowledge. Journal of Personality and Social Psychology 49 (2), $436 i ̈ 458$ (1985)

11. Wei Y., Yan H., Bie R., Wang S., Sun L.: Performance monitoring and evaluation in dance teaching with mobile sensing technology. Personal and Ubiquitous Computing 18 (8), 1929 1939 (2014)

12. Li H., Lu M., Chan G., Skitmore M.: Proactive training system for safe and efficient precast installation. Automation in Construction 49, Part A, 163 Ï 174 (2015)

13. Prabhu V.A., Elkington M., Crowley D., Tiwari A., Ward C.: Digitisation of manual composite layup task knowledge using gaming technology. Composites Part B: Engineering 112, 314ї 326 (2017)

14. Jang S.-A., Kim H.-i., Woo W., Wakefield G.: AiRSculpt: A Wearable Augmented Reality 3D Sculpting System. In: Streitz, Markopoulos (eds.): Proc. DAPI 2014. pp. 13010141. Springer, Cham (2014)

15. Meleiro P., Rodrigues R., Jacob J., Marques T.: Natural User Interfaces in the Motor Development of Disabled Children. Procedia Technology 13, 66 ï 75 (2014)

16. Araki A., Makiyama K., Yamanaka H., Ueno D., Osaka K., Nagasaka M., Yamada T., Yao M.: Comparison of the performance of experienced and novice surgeons. Surgical Endoscopy 31 (4), 1999ï 2005 (2017)

17. Asadipour A., Debattista K., Chalmers A.: Visuohaptic augmented feedback for enhancing motor skills acquisition. The Visual Computer 33 (4), 401 ï 411 (2017)

18. Kim S., Dey A.K.: Augmenting human senses to improve the user experience in cars. Multimedia Tools and Applications 75 (16), $9587 і ̈ 9607$ (2016)

19. Ke F., Lee S., Xu X.: Teaching training in a mixed-reality integrated learning environment. Computers in Human Behavior 62, 212 ï 220 (2016)

20. Duente T., Pfeiffer M., Rohs M.: On-skin technologies for muscle sensing and actuation. In: Proc. UbiCompôl6, pp. 933ї 936. ACM, New York (2016)

21. Kwon Y., Lee S., Jeong J., Kim W.: HeartiSense: a novel approach to enable effective basic life support training without an instructor. In: CHI '14 Extended Abstracts on Human Factors in Computing Systems, pp. 431ї 434. ACM, New York, NY (2014)

22. Benedetti F., Catenacci Volpi N., Parisi L., Sartori G.: Attention Training with an Easyï toï Use Brain Computer Interface. In: Shumaker, Lackey (eds.) Proc. Virtual, Augmented and Mixed Reality (VAMRôl4), pp. 236ï 247. Springer, Cham (2014)

23. Kowalewski K.-F., Hendrie J.D., Schmidt M.W., Garrow C.R., Bruckner T., Proctor T., Paul S., Adigüzel D., Bodenstedt S., Erben A., Kenngott H., Erben Y., Speidel S., Müller-Stich B.P., Nickel F.: Development and validation of a sensor- and expert model-based training system for laparoscopic surgery: the iSurgeon. Surgical Endoscopy, 1 ï 11 (2016)

24. Sanfilippo F.: A multi-sensor fusion framework for improving situational awareness in demanding maritime training. Reliability Engineering \& System Safety 161, 12ї 24 (2017)

25. Sharma P., Wild F., Klemke R., Helin K., Azam T.: Requirement analysis and sensor specifications: First version. WEKIT, D3.1, (2016). 